\title{
PENERAPAN TRANSFORMASI GEOMETRI PADA DESAIN BATIK LIA MAIDO MENGGUNAKAN DESMOS
}

\author{
Hidayati ${ }^{1)}$ \\ Sugeng ${ }^{2)}$ \\ 1) SMA Negeri 1 Nunukan, Kalimantan Utara \\ 2) Program Studi Pendidikan Matematika, Universitas Mulawarman \\ Email: ${ }^{1}$ hidayati.nnk@gmail.com \\ ${ }^{2}$ sugeng@fkip.unmul.ac.id
}

\begin{abstract}
ABSTRAK
Artikel ini bertujuan mendeskripsikan pembelajaran berkaitan dengan penerapan konsep transformasi geometri menjadi desain batik Lia Maido menggunakan aplikasi Desmos. Lia Maido berasal dari bahasa Tidung dan Toraja. Lia berarti merah dan Maido berarti hijau. Penggunaan desmos sebagai proses literasi digital bagi guru dan peserta didik pada pembelajaran matematika tentang transformasi geometri. Penerapan konsep transformasi geometri dalam membuat desain batik Lia Maido menggunakan aplikasi desmos dilakukan dalam tiga tahapan. Tahap pertama merancang bangun utama yang akan ditransformasikan, pada desain batik Lia Maido, terdiri atas tiga bangun utama yaitu bidang segi delapan beraturan, bidang persegi, dan bidang segi enam. Tahap kedua mengakses aplikasi desmos dan membuat folder untuk memasukkan titik koordinat dari tiga bangun utama. Tahap ketiga melakukan proses transformasi geometri dari tiga bangun utama di desmos, sehingga diperoleh 3 bangun hasil translasi, 71 bangun hasil refleksi dan 23 bangun hasil rotasi. Penerapan transformasi geometri dalam desain batik melatih peserta didik berfikir kritis, kreatif dalam memecahkan masalah sehingga diperoleh desain pola batik yang diharapkan .Desain batik Lia Maido dari SMAN 1 Nunukan telah berhasil direalisasikan menjadi kain batik, yang di dalamnya memuat materi Transformasi Geometri yaitu Translasi (pergeseran), Refleksi (pencerminan), dan Rotasi (perputaran).
\end{abstract}

Kata kunci: Transformasi Geometri, Desain batik Lia Maido, Desmos

\begin{abstract}
This article aims to describe learning related to the application of geometric transformation into Lia Maido batik designs using Desmos. Lia Maido comes from the Tidung and Toraja languages. Lia means red and Maido means green. The use of desmos as a digital literacy process for teachers and students in learning mathematics about geometric transformations. The application of geometric transformation in making Lia Maido batik designs using Desmos was carried out in three stages. The first stage was to design the main shape to be transformed, in Lia Maido batik design, it consists of three main shapes, namely a regular octagon, a square, and a hexagon. The second step was to access Desmos and created a folder to enter the coordinates of the three main shapes.
\end{abstract}


The third step was to transform three main shapes in Desmos, so that 3 figures are translated, 71 are reflections and 23 are rotations.The application of geometric transformation in batik design trains students to think critically, creatively in solving problems so that the expected batik pattern design is obtained. Lia Maido batik design from SMAN 1 Nunukan has been successfully printed on cloth, which contains Geometric Transformation material, namely Translation, Reflection, and Rotation.

Keywords: Geometry Transformation, Lia Maido's batik design, Desmos

\section{PENDAHULUAN}

Batik adalah kebudayaan Indonesia yang sudah mendunia dan diakui oleh UNESCO pada 2 Oktober 2009, sebagai warisan kemanusiaan untuk karya lisan dan non bendawi (Masterpieces of the Oral and Intangible Heritage of Humanity). Batik memiliki kekhasan maupun keunikan yang membedakan bangsa Indonesia dengan bangsa lain. Keindahan batik dapat dinikmati dari bentuk-bentuk artistik yang dituangkan pada lembaran kain. Beberapa bentuk artistik yang tampak pada desain batik adalah bangun-bangun geometri. Bangun geometri yang sering dijumpai pada kain batik dapat berupa titik, garis dan bidang datar. Bidang datar tersebut misalnya poligon (jajar genjang, persegi, segi enam, dll) irisan kerucut (elips, lingkaran, parabola, hiperbola). Bentuk-bentuk artistik yang memuat bangun geometri pada batik, menyebabkan batik digunakan sebagai alat atau media dalam pembelajaran matematika, khususnya pada materi transformasi geometri. Hal inilah yang mendasari penelitian ini untuk menerapkan konsep matematika yaitu konsep transformasi geometri dalam menciptakan batik Lia Maido. Penerapan transformasi geometri ke dalam desain batik melatih peserta didik berfikir kritis, kreatif dalam menyelesaikan masalah dan menciptakan pola batik yang diinginkan. Lia Maido berasal dari bahasa Tidung dan Toraja. Lia berarti merah dan Maido berarti hijau. Desain batik Lia Maido pada awalnya adalah desain batik yang dibuat oleh sekelompok peserta didik sebagai tugas pada pembelajaran transformasi geometri. Desain batik Lia Maido ini kemudian disempurnakan oleh guru dengan mendesain ulang pada aplikasi desmos sebagai media pembelajaran transformasi geometri berbasis digital.

Desmos is an online graphing utility that requires no download or special hardware. It works on any tablet, phone or computer (Ebert, 2015). Website ini dapat membantu guru dalam memvisualisasikan topik yang diajarkan kepada peserta didik sehingga pembelajaran bisa lebih bermakna (Ishartono dkk, 2018). Desmos adalah paradigma baru dalam belajar, aplikasi desmos merupakan prototipe masa depan yang dikembangkan untuk mengubah cara berfikir peserta didik dalam belajar matematika. Memfasilitasi peserta didik melalui beragam kegiatan yang menarik yang akan menginspirasi mereka agar berkreaasi menggunakan teknologi adalah upaya guru untuk mengalihkan peserta didik dari pembelajaran konvensional ke pembelajaran digital. Desmos tidak hanya memberikan pengalaman belajar kepada peserta didik bagaimana menggunakan alat tersebut, tetapi mereka juga belajar

100 Penerapan Transformasi Geometri Pada Desain Batik Lia Maido Menggunakan Desmos Hidayati - Sugeng 
banyak tentang matematika terutama belajar membuat grafik. Learning Outcomes By the end of learning process provided by the present module, it is expected that the teachers will be able to: (a) Create problem-solving, investigative, and real-life tasks to promote students' understanding about mathematical ideas. (b) Use Desmos as graphing calculator and digital activity builder to make effective mathematical tasks that facilitate students' learning ( Kristanto Y. D, 2019). A tool that can be used to engage students innovatively in mathematics is Desmos. Desmos is a free online graphing calculator that runs as a browser application, and also as a mobile app. For this class project, the students were asked to create a drawing with Desmos, using different functions and their transformations (King, A, 2017).

Materi transformasi geometri, merupakan materi yang sangat menarik apabila konsepnya bisa dipahami dengan benar, akan tetapi beberapa peserta didik di sekolah mengalami kesulitan mempelajari materi ini. Berdasarkan penelitian yang sudah dilakukan bahwa peserta didik mengalami kesulitan dalam memahami konsep transformasi meliputi translasi, refleksi, rotasi, dilatasi dan kombinasi transformasi geometri (Albab dkk, 2014); yang secara keseluruhan, kesalahan peserta didik dominan berbentuk kesalahan konsep (Maulani dan Zhanty, 2020). Kesulitan peserta didik dalam memahami materi sehingga memunculkan kesalahan konsep, tentu saja bisa diatasi apabila mengenal, memahami konsep transformasi dengan benar, serta dapat menerapkannya dalam menyelesaikan masalah. Pada materi transformasi geometri ini, visualisasi obyek yang ditransformasikan sangat penting untuk membantu peserta didik memahami konsepnya.

Bentuk-bentuk artistik pada batik, menyebabkan batik digunakan sebagai media pembelajaran matematika, khususnya pada materi transformasi geometri. Seperti pada penelitian Novrika, dkk (2016) yang mendesain pembelajaran refleksi menggunakan motif kain batik, ternyata penggunaan motif kain batik sangat membantu peserta didik dalam memahami materi refleksi (pencerminan) baik refleksi suatu obyek maupun refleksi terhadap garis-garis pada koordinat kartesius. Hal ini juga sejalan dengan pendapat Sudirman, dkk (2017) bahwa pada pola bentuk motif batik dapat menjadi alternatif sumber belajar matematika bagi peserta didik, dan dapat menambah wawasan peserta didik mengenai keberadaan matematika yang ada pada salah satu unsur budaya Indonesia. Namun, dari beberapa hasil penelitian sebelumnya, batik hanya dijadikan media pembelajaran untuk memberikan pemahaman tentang konsep transformasi geometri, dan masih menggunakan cara manual untuk memvisualisasikannya. Belum tampak proses berfikir kritis serta kreativitas, untuk menciptakan batik dengan menerapkan konsep transformasi geometri, sehingga muncul batik dengan nuansa yang baru sebagai gagasan maupun karya nyata yang relatif berbeda dengan apa yang telah ada. Hal inilah yang mendasari guru merancang strategi pembelajaran penerapan transformasi geometri untuk menciptakan desain batik 
(batik Lia Maido) menggunakan aplikasi desmos.

\section{METODE PENELITIAN}

Metode penelitian ini adalah metode deskriptif kualitatif tentang penerapan transformasi geometri untuk mendesain motif batik, yang disajikan dalam 3 tahapan, yaitu, tahap perencanaan, tahap pelaksanaan dan tahap evaluasi. Pada tahap perencanaan, guru merancang bahan ajar dalam PPT yang mejelaskan konsep transformasi geometri serta contoh desain pola batik dengan penerapan transformasi geometri. Pada tahap pelaksanaan guru menggunakan media pembelajaran papan transformasi geometri dan kertas berpetak untuk memfasilitasi peserta didik memahami konsep transformasi geometri dengan benar. Setelah peserta didik memahami konsepnya dengan benar, secara berkelompok peserta didik mulai berkolaborasi dan berkreasi mendesain pola batik yang diiginkan sesuai dengan kesepakatan kelompoknya. Selama tahap pelaksanaan guru menjadi fasilitator serta membimbing kelompok peserta didik yang mengalami kesulitan dalam menyelesaikan polanya. Pada tahap evaluasi guru kemudian memilih beberapa desain pola/motif batik yang kemudian didesain ulang pada aplikasi desmos, lalu diterapkan pada kain untuk selanjutnya menjadi kain batik.

Proses pembelajaran dengan menerapkan transformasi geometri ini berlangsung sejak tahun 2016 hingga sekarang. Pada tahun 2021 ini guru kemudian menyempurnakan desain batik yang dibuat secara manual oleh peserta didik, dengan menggunakan aplikasi desmos.

\section{HASIL PENELITIAN DAN PEMBA- HASAN}

Lia Maido adalah desain motif batik yang tercipta berdasarkan kreativitas peserta didik ketika mempelajari materi tentang transformasi geometri Pendekatan pemahaman konsep transformasi geometri menggunakan batik ternyata cukup banyak menjadi subjek penelitian, diantaranya oleh Christanti, dkk (2020), yang menyatakan bahwa, Secara matematis, motif kawung dapat didekati dengan bangun datar berbentuk elips. Elips yang digunakan merupakan elips horizontal yang kemudian dirotasikan dengan sudut putar $45^{\circ}$. Hasil dari elips tersebut dapat ditransformasikan dengan rotasi, refleksi dan translasi untuk menyusun suatu motif batik kawung. Dengan demikian dapat ditunjukkan bahwa terdapat aspek matematis dalam unsur budaya Yogyakarta yaitu motif batik kawung. Hal ini juga didukung oleh penelitian Novrika, dkk (2016) yang menyatakan bahwa, penggunaan motif kain batik sangat membantu siswa dalam memahami materi refleksi (pencerminan) baik refleksi suatu obyek maupun refleksi terhadap garis-garis pada koordinat kartesius. 
Tabel 1. Hasil TransformaginGueometrivolume 10, Nomor 2, Desember 2021

\begin{tabular}{|c|c|}
\hline Jenis Transformasi geometri & $\begin{array}{l}\text { Proses transformasi geometri dari } 3 \text { bangun } \\
\text { utama }\end{array}$ \\
\hline $\begin{array}{l}\text { Translasi } \\
\text { ( } 3 \text { bangun) }\end{array}$ & $\begin{array}{l}\text { Bangun } 4 \text { dan } 5 \text { transalasi bangun } 1 \text { dan } 2 \text { sejauh } \\
\mathrm{T}(2,2) \\
\text { Bangun } 11 \text { translasi bangun } 10 \text { sejauh } \mathrm{T}(-1,-2)\end{array}$ \\
\hline $\begin{array}{l}\text { Refleksi } \\
\text { ( } 71 \text { bangun) }\end{array}$ & $\begin{array}{l}\text { Bangun } 6 \text {, dan } 7 \text { refleksi bangun } 1 \text {, dan } 2 \text { terhadap } \\
\text { garis } x=3,5 \\
\text { Bangun } 8 \text {, dan } 9 \text { refleksi bangun } 4 \text {, dan } 5 \text { terhadap } \\
\text { garis y }=3,5 \\
\text { Bangun } 12,13 \text { s.d } 22 \text { refleksi bangun } 1,2 \text {, s.d } 11 \\
\text { terhadap sumbu y } \\
\text { Bangun } 34,35 \text {, s.d } 44 \text { refleksi bangun } 1,2 \text {, s.d } 11 \\
\text { terhadap sumbu x } \\
\text { Bangun } 45,46 \text {, s.d } 55 \text { refleksi bangun } 1,2 \text {, s.d } 11 \\
\text { terhadap garis } x=10 \\
\text { Bangun } 67,68 \text {, dan } 69 \text { refleksi bangun } 47,54 \text {, dan } \\
55 \text { terhadap garis x }=16,5 \\
\text { Bangun } 70,71 \text {, dan } 72 \text { refleksi bangun } 67,68 \text {, dan } \\
69 \text { terhadap sumbu x ( garis y =0) } \\
\text { Bangun } 73,74,75 \text { s.d } 100 \text { adalah refleksi bangun } \\
45,46,47 \text { s.d } 72 \text { terhadap sumbu x. }\end{array}$ \\
\hline $\begin{array}{l}\text { Rotasi } \\
\text { ( } 23 \text { bangun) }\end{array}$ & $\begin{array}{l}\text { Bangun } 10 \text { Rotasi bangun } 3 \text { pusat ( } 6,3 \text { ) sudut } \\
\text { rotasi } 90 \text { derajat. } \\
\text { Bangun } 23,24 \text { s.d } 33 \text { rotasi bangun } 1,2 \text {, s.d } 11 \\
\text { pusat }(0,0 \text { ) sudut rotasi } 180 \text { derajat. } \\
\text { Bangun } 56,57 \text { s.d } 66 \text { rotasi bangun } 1,2 \text { s.d } 11 \\
\text { pusat }(10,0 \text { ) sudut rotasi } 180 \text { derajat arah rotasi } \\
\text { searah jarum jam. }\end{array}$ \\
\hline
\end{tabular}

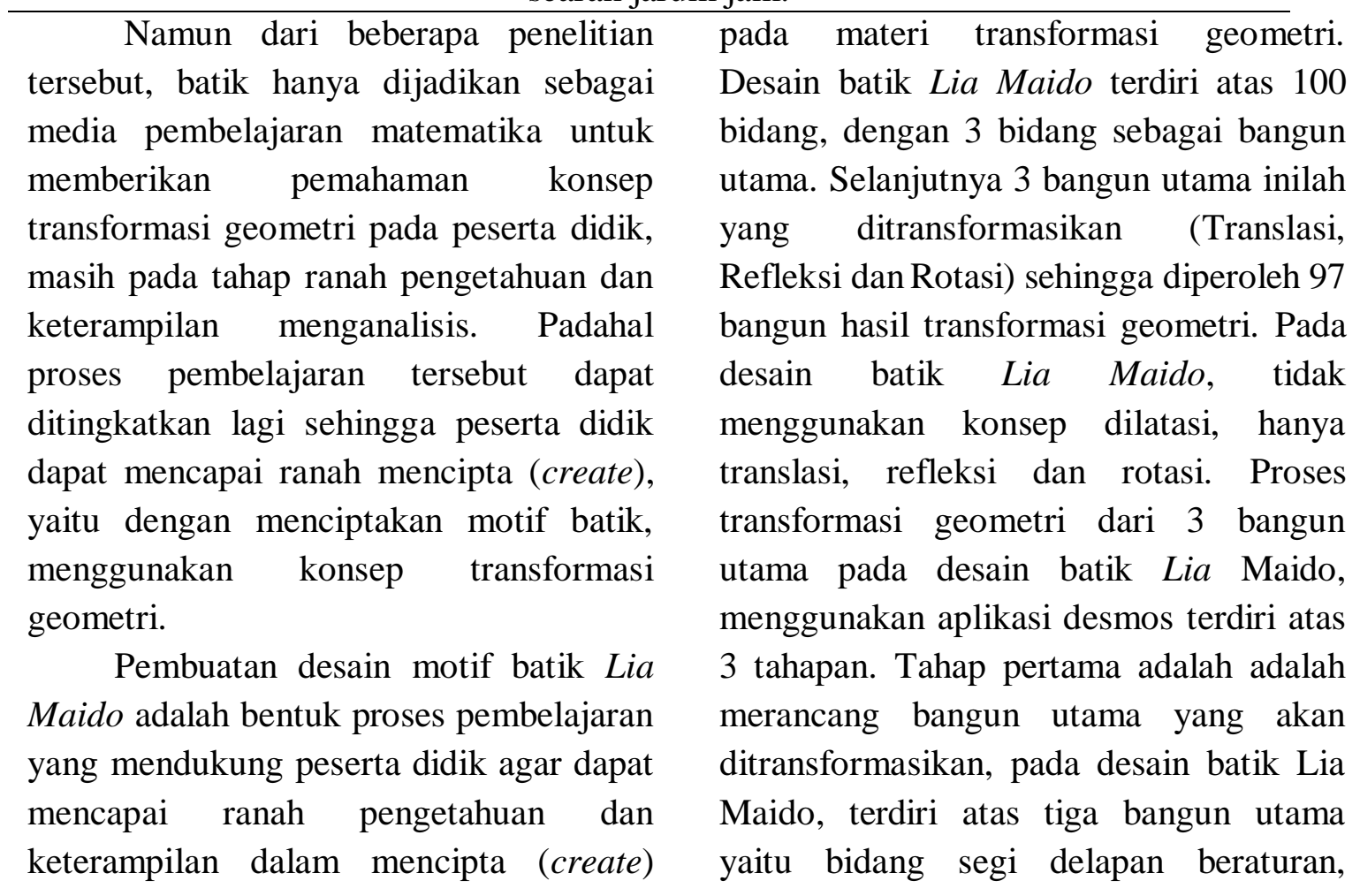


bidang persegi, dan bidang segi enam. Tahap kedua adalah 1) Mengakses desmos di www.desmos.com, lalu sign in dengan akun google, 2) Memulai membuat desain dengan memilih graphing calculator, 3) Membuat folder untuk memasukkan koordinat 3 bangun utama (bangun awal). Tahap ketiga adalah melakukan proses transformasi geometri dari 3 bangun utama, sehingga diperoleh motif batik Lia Maido.

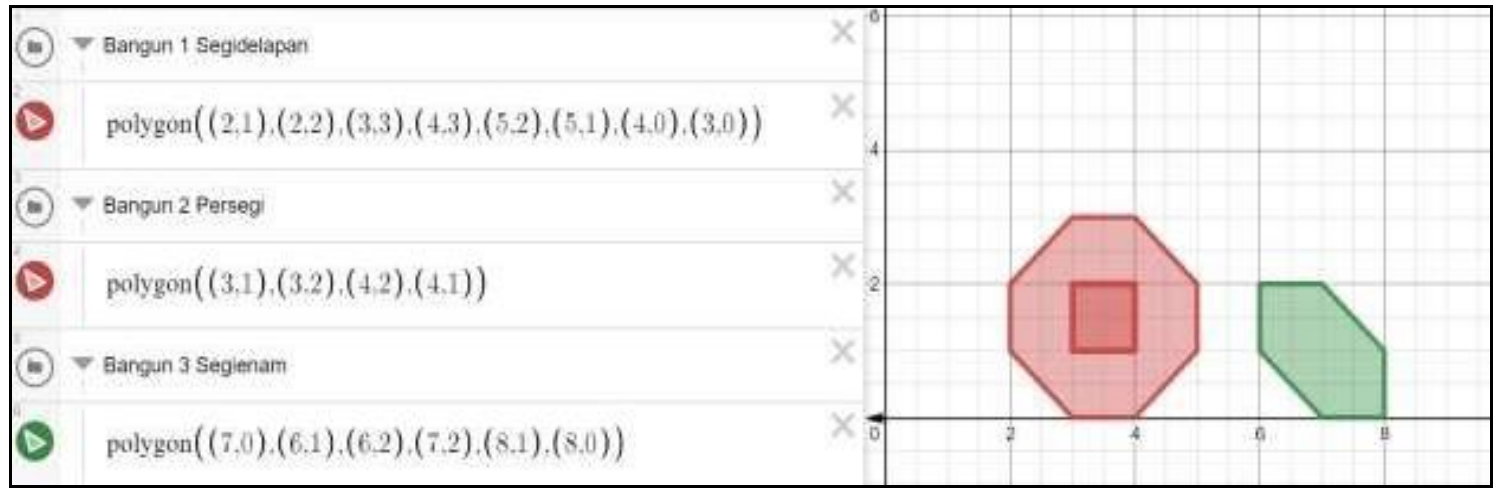

Gambar 1. Bangun utama Lia Maido pada desmos

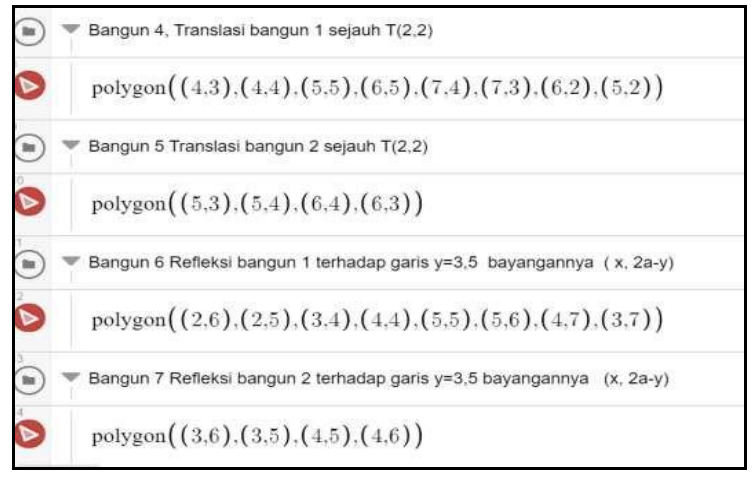

Gambar 2. Proses transformasi geometri

Desain batik Lia Maido terdiri atas 100 bangun, dengan 3 bangun utama (bidang segi delapan beraturan, bidang persegi, dan bidang segi enam). Bidang segi delapan beraturan adalah bangun nomor 1, bidang persegi adalah bangun nomor 2, dan bidang segi enam adalah bangun nomor 3. Selanjutnya 3 bangun utama inilah yang ditransformasikan sehingga diperoleh 97 bangun hasil transformasi geometri yang terdiri atas 3 bangun hasil transalasi, 71 bangun hasil refleksi, dan 23 bangun hasil rotasi. Tabel

1. Memperlihatkan hasil transformasi geometri. Proses transformasi geometri berurutan sesuai nomor bangun, dimulai dengan nomor 4, lanjut sampai bangun nomor 100. Bangun 4 dan 5 adalah hasil translasi dari bangun 1 dan 2 sejauh $\mathrm{T}$ $(2,2)$. Bangun 6 dan 7 adalah refleksi bangun 1 dan 2 terhadap garis $\mathrm{x}=3,5$. Bangun 8 dan 9 adalah refleksi bangun 4 dan 5 terhadap garis $\mathrm{y}=3,5$. Proses transformasi geometri dari setiap bangun dilakukan menggunakakan aplikasi desmos. Saat mentransformasikan, sangat penting pemahaman tentang konsep transformasi geometri (translasi, refleksi dan rotasi), karena proses perhitungan transformasinya tetap dilakukan secara manual, hanya grafiknya saja yang langsung muncul, tanpa perlu lagi digambarkan secara manual.

Desmos adalah aplikasi yang mudah dan nyaman digunakan, pernyataan ini sejalan dengan pendapat Yosep Dwi Kristanto (2021) yang menyatakan bahwa, desmos adalah aplikasi yang menawarkan berbagai 
macam sarana matematika, aktivitas matematika digital, dan memfasilitasi peserta didik belajar tingkat tinggi secara menyenangkan. Gambar 1 adalah gambar 3 bangun utama (bidang segi delapan beraturan, bidang persegi, dan bidang segi enam). Gambar 2 adalah gambar beberapa proses transformasi geometri pada desmos. Penggunaan aplikasi desmos untuk mentransformasikan bangun utama yang membentuk desain batik Lia Maido sangat mendukung proses berfikir kritis peserta didik.

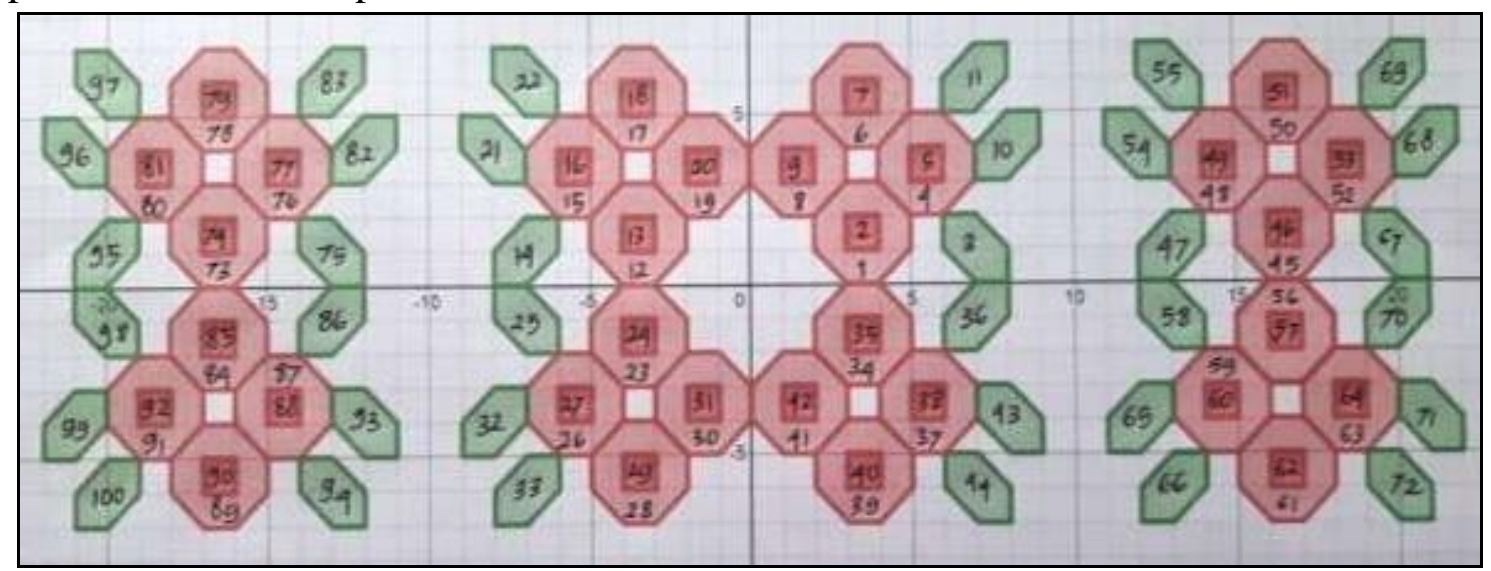

Gambar 3. Desain batik Lia Maido

Gambar 3, adalah gambar desain motif batik Lia Maido yang terdiri atas 100 bangun. Desain batik yang sudah selesai, selanjutnya diterapkan pada kain batik. Untuk proses pembuatan batik Lia Maido, guru bekerjasama dengan pengrajin batik di kota Solo.

\section{KESIMPULAN}

Pembelajaran materi transformasi geometri dengan cara membuat desain batik sangat mendukung poses berfikir kritis dan kreatifitas guru dan peserta didik. Desmos adalah paradigma baru dalam belajar, aplikasi desmos merupakan prototipe masa depan yang dikembangkan untuk mengubah cara berfikir peserta didik dalam belajar matematika. Penggunaan desmos untuk memvisualisasikan desain batik Lia Maido sangat mendukung literasi digital dalam matematika. Beragam desain batik yang dihasilkan dalam proses pembelajaran transformasi geometri, begitu menambah khazanah batik sebagai warisan budaya bangsa Indonesia.

\section{DAFTAR PUSTAKA}

Albab, I. U., Hartono, Y., \& Darmawijoyo. (2014). Kemajuan Belajar Peserta didik pada Geometri Transformasi
Proses transformasi geometri dari 3 bangun utama menggunakan aplikasi desmos terus berlanjut, sehingga diperoleh desain batik Lia Maido yang terdiri atas 100 bangun dengan 3 bangun utama serta 97 bangun hasil transformasi geometri yang terdiri atas 3 bangun hasil transalasi, 71 bangun hasil refleksi, dan 23 bangun hasil rotasi. 
Menggunakan Aktivitas Refleksi Geometri. Jurnal Ilmiah Cakrawala Pendidikan, (3), 338-348. https://doi.org/10.21831/cp.v3i3.23 $\underline{78}$

Desmos. (n.d.). About Us. Retrieved https://www.desmos.com/about.

Ebert, D. (2015). Graphing Projects with Desmos. The Mathematics Teacher, 108(5), 388-391. https://doi.org/10.5951/mathteacher .108 .5 .0388

Indra, R.I., Novrika, D., Hartono, Y. (2020). Desain Pembelajaran Materi Refleksi Menggunakan Motif Kain Batik Untuk Peserta didik Kelas VII. Prosiding Seminar Matematika dan Pendidikan Matematika 2, hal 607-626.

King, A. (2017). Using Desmos to Draw in Mathematics. Australian Mathematics Teacher, 73(2), 3337.

Kristanto, Y. D. (2019). Creating Interactive and Mathematically Rich Activity with Desmos. In Learning Mathematics Joyfully and Meaningfully. SEAMEO Regional Centre for QITEP in Mathematics.

Maulani, F.I., Zanthy, L.S. (2020). Analisis Kesulitan Peserta didik Dalam Menyelesaikan Soal Materi Transformasi Geometri. Skripsi. Cimahi: Pendidikan Matematika, IKIP Siliwangi.

Prasetyo, S.A. (2016). Karakteristik Motif Batik Kendal Interpretasi dari Wilayah dan Letak Geografis. Imajinasi: Jurnal Seni, 10 (1), 5160.

https://doi.org/10.15294/imajinasi.v $\underline{10 i 1.8816}$
Sudirman, S., Rosyadi, R., Lestari, W.D. (2017). Penggunaan Etnomatematika Pada Karya Seni Batik Indramayu Dalam Pembelajaran Geometri Transformasi. Pedagogy: Jurnal Pendidikan Matematika. Vol 2, No. 1.

Trixie, A.A,. (2020). Filosofi Motif Batik Sebagai Identitas Bangsa Indonesia. Skripsi. Surabaya: Fakultas Industri Kreatif, Universitas Ciputra. 